\title{
報酬受け取りの主観的確率判断と確率価値割引の 報酬量効果の関係
}

\section{磯村美恵子＼cjkstart青山謙二郎 同志社大学}

\author{
Subjective probability of reward receipt and the magnitude effect in probability discounting \\ Mieko Isomura and Kenjiro Aoyama (Doshisha University)
}

\begin{abstract}
Previous research suggested that larger probabilistic rewards were discounted more steeply than smaller probabilistic rewards (the magnitude effect). This research tests the hypothesis that the magnitude effect reflects the extent to which individuals distrust the stated probability of receiving different amounts of rewards. The participants were 105 college students. Probability discounting of two different amounts of rewards $(5000$ yen and 100000 yen) and the subjective probability of reward receipt of the different amounts (5000 yen, 100000 yen and 1000000 yen) were measured. The probabilistic 100000 yen was discounted more steeply than the probabilistic 5000 yen. The subjective probability of reward receipt was higher in the 5000 yen than in the 100000 yen condition. The proportion of subjective probability of receiving 5000 yen to that of receiving 100000 yen was significantly correlated with the proportion of degree of probability discounting for 5000 yen to that for 100000 yen. These results were consistent with the hypothesis stated above.
\end{abstract}

Key words: probability discounting, magnitude effect, subjective probability of reward receipt.

The Japanese Journal of Psychology

2008, Vol. 79, No. 2, pp. 172-178

確率による価值割引が生じることが過去の研究で明 らかにされている（Rachlin, Raineri, \& Cross, 1991; 佐 伯，2001）。確率による価值割引は，確実に受け取る ことができる少額の報酬と受け取りが不確実な多額の 報酬との選択から知ることができる。例えば, “確実 な 7 万円”と“ $80 \%$ の 10 万円”のどちらかを選択す る場合, 多くの人は“確実な 7 万円” を選択する。こ れは， $80 \%$ という確率が伴うことで 10 万円の価值が 割り引かれたためと考えられ, これを確率価值割引と いう。そして，このような割引の程度を知るために は，例えば，確実な報酬の金額のみを低下させ(“確 実な 6 万円”と“ $80 \%$ の 10 万円”), さらに選択を求 める。この過程を繰り返すと, ある金額において選好 が変化し，不確実な多額の報酬を選ぶようになる。例 えば，“確実な 6 万円”と“ $80 \%$ の 10 万円”では，前 者を選択するが，“確実な 5 万円”と“ $80 \%$ の 10 万 円”では, 後者を選択するというような選好の変化が 生じる。この場合，6万円と 5 万円の間のどこかで選 好が変化したと考えることができる。そして，便宜的

Correspondence concerning this article should be sent to: Mieko Isomura, Department of Psychology, Doshisha University, Karasuma Imadegawa, Kamigyo-ku, Kyoto 602-8580, Japan (e-mail: taikun3@livedoor.com)
に選好の変化が生じた選択項目の直前と直後の確実な 金額を平均したもの，つまり，6万円と 5 万円の間の 5 万 5 千円で選好が変化したと通常は推測する。言い 換えると，確実な 5 万 5 千円と $80 \%$ の 10 万円との主 観的な価值がほぼ等価であるといえる。このように調 べると, 報酬の受け取りに確率が伴うとその報酬の主 観的価值は低くなり, 受け取ることができる確率が低 いほど報酬の主観的価值は低くなることがわかる。

そして，このような確率による主観的価值の推移は 双曲線関数 $V=A /(1+h \Theta)$ によりうまく記述できる (Green, Myerson, \& Ostaszewski, 1999)。Vは報酬の主 観的価值，A 確率を伴う報酬量， $\Theta$ はオッズアゲイ ンストを表している。 $h$ は割引の程度を表す経験定数 (フリーパラメータ) である。オッズアゲインストは $(1-p) / p$ で求められ ( $p$ は受け取る確率), 確率報酬 の受け取りの機会が何度も繰り返されると仮定した場 合, 確率報酬の受け取りまでにどの程度の回数外れる かを平均したものである。例えば，20\%の受け取り確 率の場合, $(1-0.2) / 0.2=4$ となる。 $50 \%$ の確率の場 合では, $(1-0.5) / 0.5=1$ となる。つまり, 受け取る 確率が低いほどオッズアゲインストは大きくなる。

また, 確率価値割引では報酬量が大きいほど割引が 激しくなるという報酬量効果が認められている。例え 
ば Green et al. (1999) では，70\%の\$200は，確実な 約 $\$ 60$ と等価である（7 割引） と評定されたが，70\% の $\$ 5000$ は, 確実な約 $\$ 1000$ と等価（8 割引）とな っている。しかし，このような報酬量効果は多くの研 究でみられているにも関わらず，なぜ報酬量効果が生 じるのかという実証的研究は行われていない。

そこで本研究では, 確率価值割引の報酬量効果が生 じる要因を検証する。そして，金額の大きさによって 主観的に受け取ることができると感じる確率が違うた め, 報酬量効果が生じるという仮説 (Green \& Myerson，2004）を基に本研究を行った。Green \& Myerson（2004）では, 確率条件の割引率 $h$ は, 個人 が報酬の受け取りに伴う確率に対して感じる信頼の程 度を反映していると示唆している。つまり，もし小報 酬よりも大報酬における確率の信頼が小さいならば, 大きな確率報酬の方が価值割引は激しいと推測でき る。Green \& Myerson (2004) では, 確率の信頼が金 額によって異なる可能性を指摘するだけで，それがど のようなものであるのか, さらになぜ大報酬ほど信頼 が小さくなるのかという根拠が述べられていない。し かし, 我々は確率に対する信頼が過去の経験によって 生じるものであり，例えば宝くじのように確率的に大 報酬が貪える状況では, 実際にはその報酬は貪えない ことを経験し，小報酬の時は貪えた経験があることに よって, このような信頼の違いが生じることが現実に ありえるだろうと考えた。しかし，金額によって確率 に対する信頼の程度が実際に違うかどうかはまだ確か められていない。そのため, 本研究の第一の目的とし て, 確率を伴う報酬の受け取りに関する主観的確率を 調べる。ある確率である金額が当たるくじ引きに 1 回 目で当たる主観的確率を評定させ，金額によって差異 があるかを確かめる。ここでは，金額が大きい方が確 率に対する信頼の程度が小さくなり, より主観的確率 が低くなると予測できる。さらに第二の目的として， 主観的確率において金額による違いがあるならば，そ れが確率価值割引の報酬量効果に関係しているかを確 かめる。もし仮説（Green \& Myerson, 2004）に従うな らば，金額の大きい方が主観的に当たりにくいと評定 した人ほど，確率価值割引において金額の大きい条件 での割引がより激しくなると推測できる。

\section{方 法}

実験参加者 大学の心理学系授業において, “報酬 の受け取りに関する調査” と題し募集した。実験参加 者は 109 名（男性 54 名, 女性 55 名), 平均年齢 19.15 $(S D=0.84)$ 歳であった。

質問紙 第一部 “選択行動実験” と第二部 “確率の ある報酬に関する調査”の二部構成であった。32 枚 を 1 冊に綴じ，1枚目は同意書，2枚目は第一部の説 明及び練習試行，3枚目は第二部の説明及び練習試
行, 4 枚目に性別及び年齢の回答欄, 5 枚目から 20 枚 目に第一部の選択問題, 21 枚目から 32 枚目に第二部 の質問を記したものを用いた。

第一部は Christensen, Parker, Silberberg, \& Hursh （1998）を参考に, 価值割引の程度を質問紙により求 めるものであった。なお, 価值割引質問紙は本研究の 目的である確率価值割引を測定するものと本研究の目 的ではない遅延価值割引を測定するものの 2 種類を用 いた。その理由は, 実験参加者が確率価值割引の回答 に関連づけて第二部の質問紙に回答することを防ぐた めである。つまり, 確率価值割引を行った直後に確率 判断を行うと, 第一部での選択記憶が第二部の主観的 確率判断に影響を与える可能性があるため間に遅延条 件を挟んだ。よって, 確率条件と遅延条件では常に確 率条件を先に実施し, 遅延条件のデー夕は分析からは 除外した。また，確率及び遅延を設定するにあたつ て, 教室にて大学生 60 名（男性 17 名, 女性 43 名) を対象とした予備実験を行った。確率は 20\%，40\%， $60 \%, 80 \%$, 遅延は 1 力月, 6 力月, 1 年, 5 年を用 いたところ, 先行研究と類似した価值割引曲線を描く ことができたため, 本研究においても各々 4 水準を用 いた。報酬量は 5000 円， 10 万円の 2 水準を用いた。 その理由は, 報酬量効果に関する初期の研究 (Green, Myerson, \& McFadden, 1997）では報酬量の水準を多く 設定していたが, 現在では典型的な差が出る大小 2 水 準を用いるのが主流となっているためである（佐伯, 2001)。

第二部は予備実験を参考にして，“○○\%の確率で $\triangle \triangle$ 円が当たるくじ引きに 1 回目で当たる確率は何\% ぐらいだと感じますか?”と尋ね, 選択形式で回答さ せた。予備実験は, 実験室にて大学生 113 名（男性 53 名, 女性 60 名）を小グループに分け, 主観的確率 を直接数字で回答させる形式をとった。しかし, 直接 数字を答えることに困難があるという感想があったた め, 回答方法を選択形式に改めた。確率は 20\%, $40 \%, 60 \%, 80 \%$ の 4 水準，報酬量は 5000 円，10 万 円，100万円の 3 水準であった。質問紙の詳細は手続 きで改めて解説する。

装置 教示のスライドをパワーポイントで作成し, 液晶プロジェクタにより，スクリーン（横 $150 \mathrm{~cm} \times$ 縦 $135 \mathrm{~cm}$ ) に映し出した。

実験状況 実験室に机 $(45 \mathrm{~cm} \times 180 \mathrm{~cm})$ を 5 台並 べた。机 1 台には 2 名ずつ着席でき, 実験には最大 10 名が一度に参加できた。机の上には質問紙, 鉛筆, 消しゴムを用意した。

手続き 質問紙 1 枚目の同意書を用いて研究目的を 説明した。同意書には, 答えたくない質問には答えな くても良い旨, また研究参加に承諾した後でも, いつ でも承諾を撤回し本研究への参加を取りやめることが できる旨, そして回答事項は全て匿名で分析され, 個 
人情報の管理に配慮している旨などを記した。そし て，2 枚目を開くように指示して，第一部の説明及び 練習試行に移つた。練習試行は報酬量 1 万円で確率を $70 \%$ ，遅延を 3 力月とした。練習試行を Figure 1 の ようにスクリーンに映し出し, 実験者が選択の見本を 行った。その後, 参加者各自で好ましい側を自由に選 択させた。

次に，3枚目に移り，第二部の説明及び練習試行を 行った。練習試行は報酬量 50 万円で確率を $30 \%$ とし た。練習試行を Figure 2 のようにスクリーンに映し 出し, 実験者が選択の見本を行った。その後, 参加者 各自で自分が感じた方に丸を付けるよう教示した。

練習後, 研究参加に同意した参加者は同意書に署名 をし，性別及び年齢を記入した。その後，5枚目から 20 枚目までの選択問題を 10 分間で行うように教示し た。
確率条件での選択は, 練習試行の 1 問目 (Figure 1a）と同様，確実に貪える小さな報酬と確率を伴う大 きな報酬の二つから選択するものであった。報酬量は 5000 円と 10 万円，確率は 80\%，60\%，40\%，20\% とした。報酬量と確率を組み合わせて 8 条件とした。 遅延条件も同様に, 報酬量と遅延期間を組み合わせて 8 条件とし, 両条件合わせて 16 条件の選択問題を用 いた。

条件ごとに以下の 19 の選択質問項目を A4 用紙に 印刷し用いた。確率条件では 1 条件の間, 右列の確率 的な報酬量は常に固定させ，左列の確実な報酬量を上 昇系列で変化させた。確率的な報酬量が 5000 円の場 合，確実な報酬量は250 円から 250 円ずつ 4750 円ま で増加させて 19 種類（250 円，500 円，ㄱ, 4500 円， 4750 円), 確率的な報酬量が 10 万円の場合, 確実な 報酬量は 5000 円から 5000 円ずっ 9 万 5000 円まで

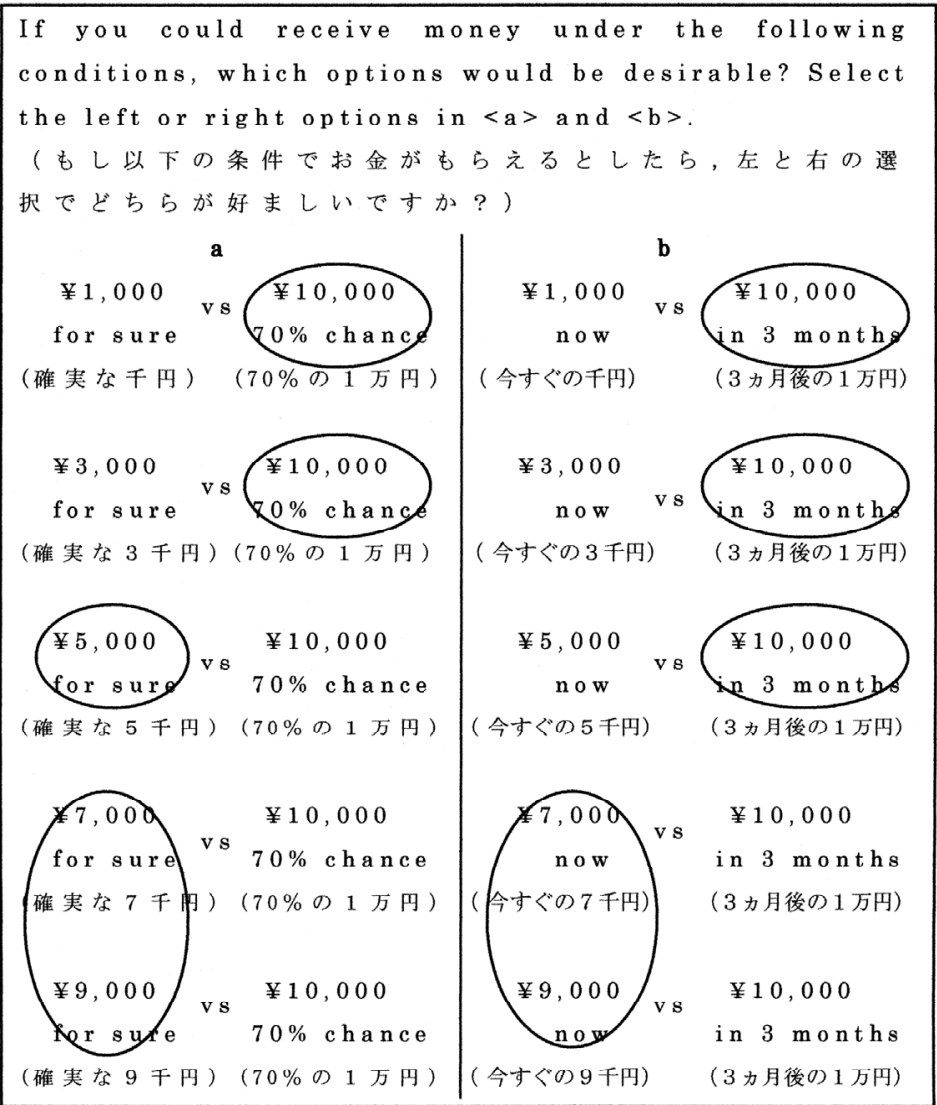

Figure 1. A sample of two series of alternatives in practice trials. The left column shows a series of successive choices between a smaller, certain, and a larger, probabilistic reward in which the amount of the smaller reward is increased. The right column shows a series of successive choices between a smaller, sooner and a larger, later reward in which the amount of the smaller reward is increased. Each circle represents a sample response drawn by the experimenter. 
増加させて 19 種類（5000円， 1 万円， …9 万円， 9 万 5000 円）であった。遅延条件も同様に，即時的な 報酬量は 19 種類とした。

条件の順序は以下の通りであった。報酬量の順序の みカウンターバランスし, 確率条件と遅延条件では常 に確率条件を先に実施した。確率あるいは遅延の提示 順序はすべて価值割引の程度が弱いものから強いもの の順（確率条件： $80 \%, 60 \%, 40 \%, 20 \%$, 遅延条 件： 1 力月， 6 力月， 1 年， 5 年）に提示した。

10 分後, 第二部は 8 分間で行うことを教示した。 報酬量は 5000 円，10万円，100 万円，確率は $20 \%$, $40 \% ， 60 \% ， 80 \%$ とした。報酬量の提示順序は第一部 にて 5000 円を先に, 10 万円を後に答えた条件の参加 者は 100 万円， 5000 円，10 万円とした。また第一部 で 10 万円を先に，5000 円を後に答えた条件の参加者 は 100 万円，10万円， 5000 円とした。全参加者にま ず 100 万円条件を行わせた。その理由は，第一部の回 答と関連づけることを少しでも防ぐためであった。確 率の提示順序は $20 \%, 40 \%, 60 \% ， 80 \%$ とした。そ の理由は, 第一部の確率条件では, $80 \%, 60 \%$, 40\%，20\%と提示したので関連づけを防ぐためであっ た。以下，第一部を価值割引実験，第二部を主観的確 率判断実験と呼ぶ。

\section{結 果}

価值割引実験について 参加者毎に第一部の確率条 件の主観的価值を求めた。選好の変化が起こった直後 の選択質問項目の確実な報酬の金額とその直前の確実 な報酬の金額との平均を算出して主観的価值とした。 例えば，Figure 1a では，70\%の確率を伴う 1 万円の 主観的価值は，3000 円と 5000 円の平均で 4000 円と なる。そして, Figure 3 には, 主観的価値を報酬量の 割合で表したものの平均値と標準偏差を示した。例え ば，20\%の確率で貪える5000 円の主観的価值が 1500 円であるならば, $1500 / 5000=0.3$ となる。横軸 は, 各確率をオッズアゲインストに変換した值であ る。Figure 3 より 10 万円の曲線の方が下にあること がわかる。

本研究では, 先行研究 (Myerson, Green, \& Warusawitharana, 2001） に従って価值割引曲線下の面 積を用いて価值割引の程度を検討した。これは, 実験 参加者毎に Figure 4 のように, 横軸は客観的確率を オッズアゲインストに変換した值, 縦軸は主観的価値 を報酬量の割合として価値割引曲線を描き, 四つの台 形 $\mathrm{a}, \mathrm{b}, \mathrm{c}, \mathrm{d}$ の面積を求め, 合算したものである。 そして，合算した面積の最大值が 1 になるように，4 で割った。なお，オッズアゲインストが 0 の時は報酬

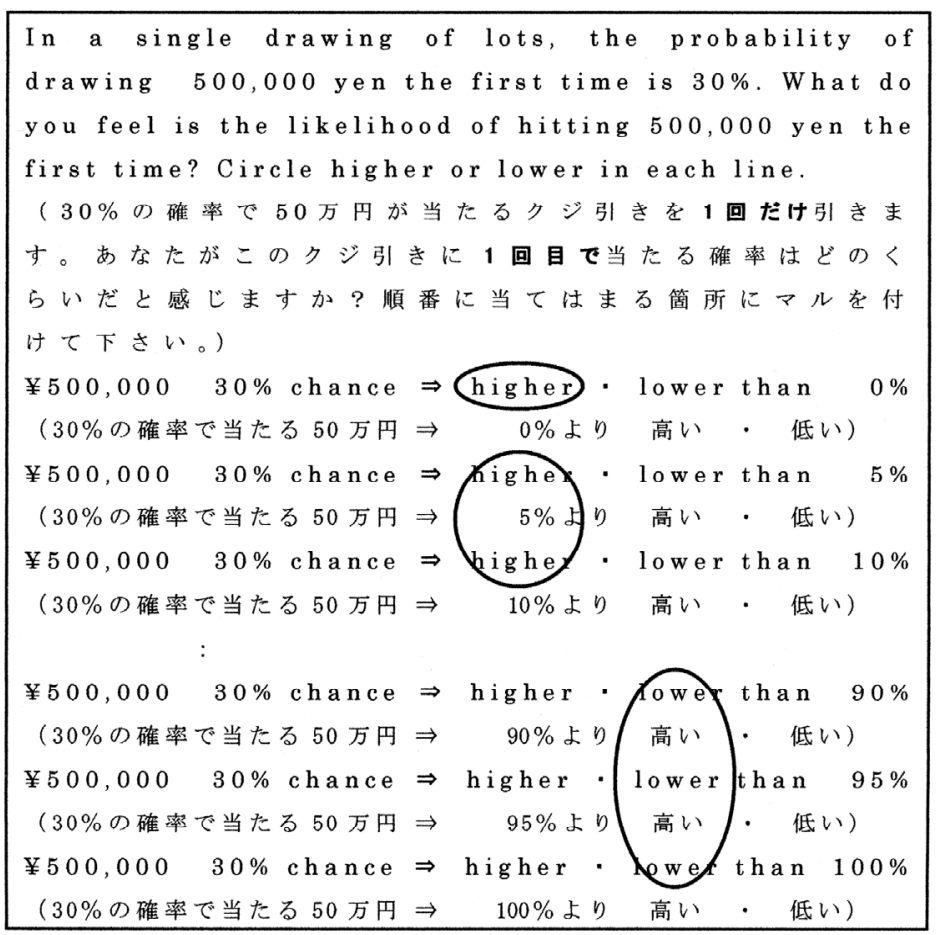

Figure 2. A sample of a series of successive choice questions about the subjective probability of a reward. Each circle represents a sample response drawn by the experimenter. 
が確実に貴える場合なので, 報酬の価値割引は一切起 こらないものとして，主観的価値を 1 とする。

このようにして算出した結果, 価值割引曲線下の面 積の平均值と標準偏差は, 5000 円条件で 0.43 (0.11)，10 万円条件で $0.31(0.12)$ であった。そし て, 対応のある $t$ 検定を行ったところ, 面積に有意な 差が見られた $(t(108)=12.24, p<.01)$ 。つまり，金 額が大きい方が価值割引は激しいといえる。これらの 結果は先行研究 (Green et al., 1999) と一致した。

主観的確率判断実験について 5000 円条件，10万 円条件の各確率において参加者が評定したくじ引きに 1 回目で当たると感じる確率の平均值と標準偏差を求 め, 客観的確率の関数として Figure 5a に示した。以 下, 参加者がくじ引きに 1 回目で当たると感じる確率 のことを主観的確率と呼ぶ。なお，100万円条件は第 一部と第二部の関連づけを防ぐ目的のものであったた め, 分析からは除外した。また, 第二部に記入漏れの

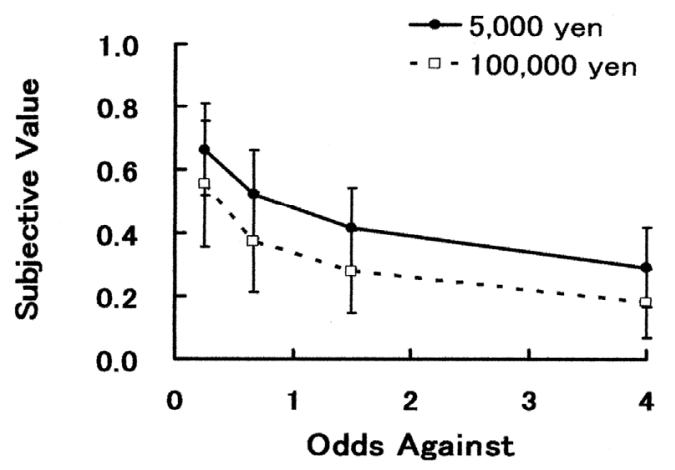

Figure 3. The subjective value of probabilistic 5000 yen and 100000 yen rewards plotted as a function of the odds against their receipt.
あった 4 名のデー夕は除外した。確率と報酬量を実験 参加者内要因とする 2 要因の分散分析を行ったとこ ろ, 確率要因の主効果が有意であった $(F(3,312)=$ $1086.89, p<.01)$ 。つまり, 客観的確率が高くなれば くじ引きに当たると感じる主観的確率は高くなるとい える。また, 報酬量要因の主効果が有意であった $(F(1,104)=99.44, p<.01)$ 。つまり，金額が高くなれ ばくじ引きに当たると感じる確率は低くなるといえ る。また, 報酬量と確率の交互作用が有意であった $(F(3,312)=11.77, p<.01)$ 。つまり, 客観的確率が低 い時は 5000 円と 10 万円の主観的確率の差は小さい が，客観的確率が高い時は 5000 円と 10 万円の主観 的確率の差は大きくなるといえる。また, 客観的確率 をオッズアゲインストに変換し, 主観的確率を客観的 確率のオッズアゲインストの関数として Figure $5 \mathrm{~b} に$ 示した。客観的確率が小さくなると主観的確率も小さ くなっているのがわかる。Figure 3 と比較してみる

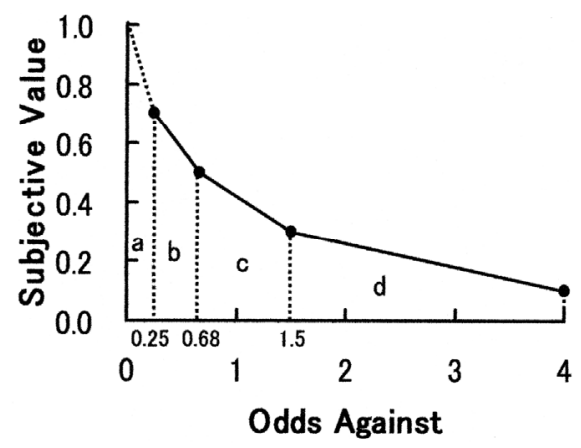

Figure 4. Calculation of the area under the value discounting curve.

a

b
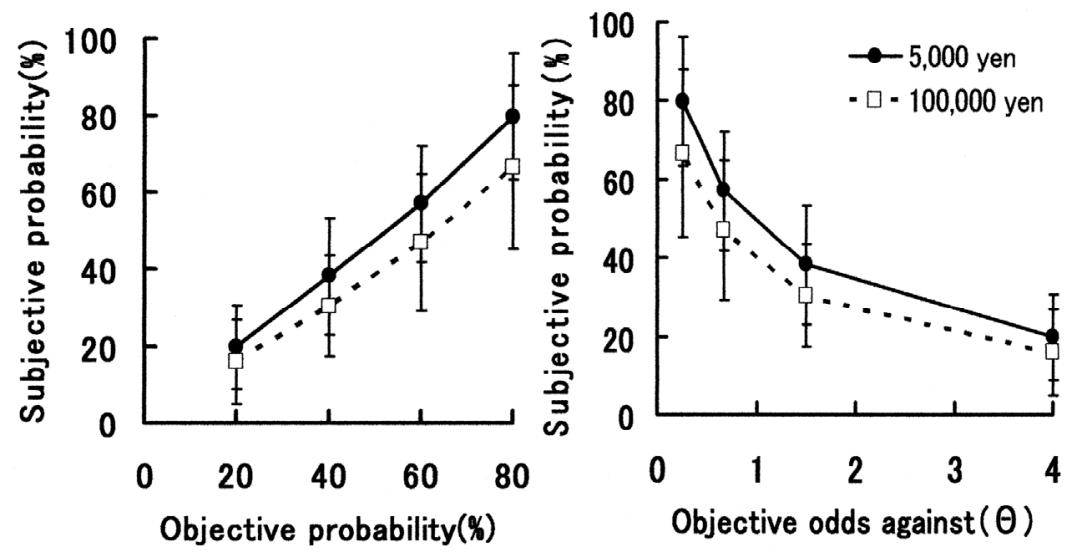

Figure 5. Subjective probability in each objective probability (a), and in each objective odds against (b). 
と, 10 万円の曲線が 5000 円の曲線よりも下にある点 が類似している。

価値割引の報酬量効果と主観的確率判断の報酬量効 果の関係 もし, 主観的確率判断における報酬量によ る違いが確率条件の報酬量効果の要因ならば, 実験参 加者ごとにみてもその関係性が認められるだろう。つ まり，5000 円の方が 10 万円よりも主観的に当たる確 率が高いと評定した参加者は, 確率価值割引において 5000 円の方が 10 万円よりも割引がゆるいと予測でき る。この関係性を確かめるために, 各実験参加者の主 観的確率と価值割引曲線下の面積を求め, 5000 円の 面積に対する 10 万円の面積の割合を算出し相関を求 めた (Figure 6)。

横軸には, Figure 5bのように表した客観的確率の 推移に伴う主観的確率の曲線下の面積を求め, 5000 円の面積に対する 10 万円の面積比（10 万円の面積 / 5000 円の面積）を示した。この場合，横軸が 1 とな った参加者は, 5000 円と 10 万円の当たると感じる主 観的確率は同じであると評定したことを表す。横軸が 1 より小さい参加者は, 5000 円の方が 10 万円より主 観的確率を高く評定したことを表す。一方，1より大 きい参加者は, 10 万円の方が 5000 円より当たりやす いと評定したといえる。縦軸には, Figure 3 のように 表した確率価值割引曲線下の面積を求め, 5000 円の 面積に対する 10 万円の面積比（10万円の面積 / 5000 円の面積) を示した。この場合, 縦軸が 1 とな った参加者は, 5000 円と 10 万円の価值割引が同じで あったことを表す。縦軸が 1 より小さい参加者は, 5000 円の方が 10 万円より価值割引が小さいことを表 し，1より大きい参加者は，10万円の方が価值割引は 小さいことを表している。その結果, 有意な正の相関 が認められた $(r=.404, n=105, p<.01) 。 つ ま り, 10$ 万円の方が 5000 円よりも主観的に当たると感じる確 率の程度が強い人ほど, 10 万円の方が 5000 円と比べ て割引の程度が䋸やかになるといえる。

しかし, Figure 6 の回㷌直線から横軸が 1 の時, 縦 軸が 1 を下回っていることがわかる。横軸が 1 という のは，5000円と 10 万円の主観的に当たると感じる確 率は等しいと評定した実験参加者である。つまり, 仮 説（Green \& Myerson, 2004）に従うなら，この実験参 加者は確率価值割引においても報酬量効果がなく, 縦 軸が 1 になるべきである。よって，主観的確率を考慮 しても 10 万円の方が割引は激しく, 報酬量効果は完 全には消えていない。

\section{考察}

本研究は, 確率価值割引の報酬量効果に焦点を当て た。報酬量の大きさによって主観的に受け取ることが できると感じる確率が違うため, 報酬量効果が生じる という仮説 (Green \& Myerson, 2004) に従うなら, あ
る確率である金額が当たるくじ引きに 1 回目で当たる 主観的確率を評定させた場合, 金額によって差異があ るはずである。さらに, 主観的確率判断の金額による 違いが, 確率価値割引の報酬量効果と関係しているは ずである。

まず, 価值割引実験では, 先行研究 (Green et al., 1999）と同様, 報酬量効果が認められた。本研究では 先行研究 (Christensen et al., 1998) にならつて質問紙 により価值割引を測定した。その他の先行研究では, 選択項目が書かれた 2 枚のカードのどちらかを選択す る方法（Rachlin et al., 1991）やパーソナルコンピュー 夕の画面に提示された選択項目を選択する方法 （Green et al., 1999）があるが, 本研究のように比較的 簡便な方法を用いても, 適切に価值割引の測定が行わ れたといえる。

次に, 主観的確率判断実験では, 同じ確率を伴う報 酬でも金額が大きい方が主観的に当たると感じる確率 は低くなった。よって, 金額が高い方が確率に対する 信頼が低く, 受け取る確率は低く感じられるだろうと いう推測 (Green \& Myerson, 2004) に一致した。

そして,この主観的確率判断における金額による違 いと確率条件の報酬量効果に関係があるかをみた。そ の結果, 5000 円の方が 10 万円よりも主観的に当たる と感じる程度が強い人ほど, 確率価值割引において 5000 円の方が 10 万円よりも割引は緩やかになるとい う傾向が認められた。このことから, 主観的確率判断 における金額による差異が, 確率価值割引の報酬量効 果の一要因になっていることが示唆できた。しかし, 本来, 仮説 (Green \& Myerson, 2004) に従うなら, 5000 円と 10 万円の主観的に当たると感じる確率が全 く同じであると評定した人は, 確率価值割引において

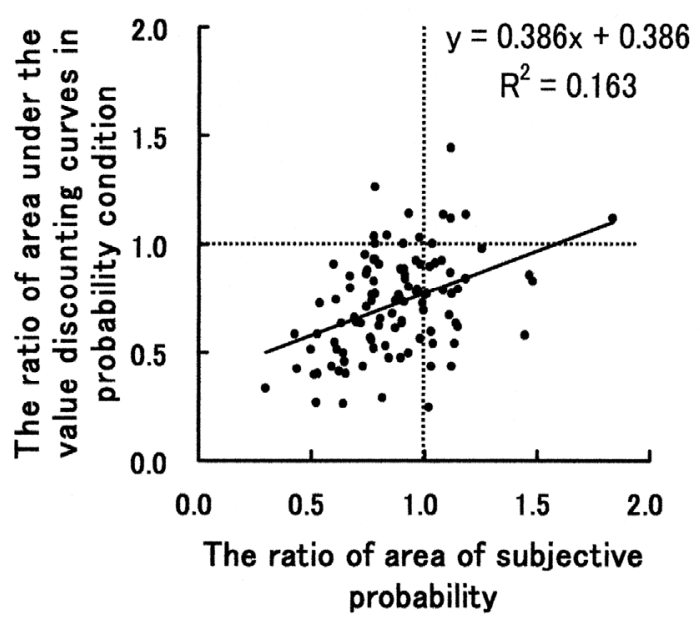

Figure 6. The ratio of area under the value discounting curves in the probability condition plotted against the ratio of area of subjective probability. 
報酬量効果が生じないはずであり， Figure 6 において 横軸（主観的確率の面積比）が 1 の時, 縦軸（価值割 引曲線下の面積比）も1 になるべきである。しかし， 結果は横軸が 1 の時, 縦軸が 1 を下回っている。つま り，当たる確率が同じであると評定した人でも，なお 10 万円の方が割引かれているといえ, 主観的確率を 考慮しても報酬量効果は消えていない。これらのこと から, 主観的確率判断における金額による違い以外に も報酬量効果の要因となっているものが存在する可能 性がある。例えば, Green et al. (1999) では, 金額に よる主観的な損失感の程度が報酬量効果と関係してい る可能性を指摘している。確率価值割引における選択 肢は“確実な小報酬の受け取り”または“確率を伴う 大報酬の受け取り”の二つであるが，“確率を伴う大 報酬”を選択した場合, “受け取りなし”という結果 がありえるため，三つの結果が存在する。そのため， 確率を伴う報酬を選択して受け取れなかった場合, 客 観的には単なる受け取りなしだが，主観的には受け取 るはずであった金額が受け取れないという損失を感じ る人が存在し，その程度が金額によって異なる可能性 を示唆している。

また本研究では, Green \& Myerson (2004) の仮説 が想定する因果関係が正しければ，みられるべき相関 関係が認められたといえる。ただし，あくまでも相関 研究であり，因果関係を証明するものではない。主観 的確率判断における金額による違いを生じさせる原因 に関しても究明しなければいけない。そこで考えられ るものの一つは個人の過去の経験である。例えば, 過 去にギャンブルなど確率を伴う場面において，大報酬 を獲得した経験がある場合，金額が高くても確率に対 する信頼は高く, 当たりにくいとは感じないであろ う。このように, 過去の経験が異なることで主観的確 率の感じ方に違いが生じ, 主観的確率の感じ方の違い が報酬量効果を生じさせるのではないかと推測でき る。一方, 過去の経験が並列的に主観的確率の感じ方 の違いと確率価值割引の報酬量効果の両方に直接影響 を与えているという可能性も考えられるので, 今後こ れらを区別する研究が必要とされる。

また, 本研究の分析からは除外した遅延価值割引
も, 確率価值割引と類似した双曲線関数を描くことが わかっている (Green et al., 1999)。このことから, 確 率及び遅延では割引のプロセスが同じであるという単 一プロセス説が提唱されている (Green et al., 1997)。 しかし, 遅延条件では報酬量が小さいほど割引が激し くなるという確率価值割引とは逆の報酬量効果が認め られている (Green et al., 1999)。これは, 単一プロセ ス説の予測に反する現象である。よって今後は, 遅延 価值割引の報酬量効果がなぜ生じるのかに関しても検 討する必要がある。

\section{引用文献}

Christensen, J., Parker, S., Silberberg, A., \& Hursh, S. (1998). Trade-offs in choice between risk and delay depend on monetary amounts. Journal of the Experimental Analysis of Behavior, 69, 123-139.

Green, L., \& Myerson, J. (2004). A discounting framework for choice with delayed and probabilistic rewards. Psychological Bulletin, 130, 769-792.

Green, L., Myerson, J., \& McFadden, E. (1997). Rate of temporal discounting decreases with amount of reward. Memory and Cognition, 25, 715-723.

Green, L., Myerson, J., \& Ostaszewski, P. (1999). Amount of reward has opposite effects on the discounting of delayed and probabilistic outcomes. Journal of Experimental Psychology: Learning, Memory, and Cognition, 25, 418-427.

Myerson, J., Green, L., \& Warusawitharana, M. (2001). Area under the curve as a measure of discounting. Journal of the Experimental Analysis of Behavior, 76, 235-243.

Rachlin, H., Raineri, A., \& Cross, D. (1991). Subjective probability and delay. Journal of the Experimental Analysis of Behavior, 55, 233-244.

佐伯大輔 (2001)。遅延・確率・共有による報酬の価 值割引 行動科学研究, 40, 29-38.

(Saeki, D. (2001). Discounting of delayed, probabilistic, and shared rewards. Behavioral Science Research, 40, 29-38.)

- 2006. 12.25 受稿, 2007. 10.27 受理—— 